\title{
IS CAFFEINE RECOMMENDED BEFORE EXERCISE? A SYSTEMATIC REVIEW \\ TO INVESTIGATE ITS IMPACT ON CARDIAC AUTONOMIC CONTROL VIA \\ HEART RATE AND ITS VARIABILITY.
}

\begin{abstract}
AUTHORS:
Cicero Jonas R. Benjamim, Brian Kliszczewicz, David M. Garner, Taisy Cinthia Ferro

Cavalcante, Amanda Alves Marcelino da Silva, Milana Drumond Ramos Santana and

Vitor E. Valenti
\end{abstract}

\section{ABSTRACT}

OBJECTIVES: Evaluating different doses of caffeine (CAF) on heart rate (HR) variability (HRV) during and following exercise in order to assess its impact on autonomic control. We intended to evaluate the influence of CAF as a supplement before exercise on HRV through a systematic review. DATA SOURCES: Manuscripts were selected based on electronic searches of MEDLINE, EMBASE and CINAHL databases from 2010 to 2019 and followed the protocol Preferred Reporting Items for Systematic Reviews and Meta-Analyzes (PRISMA). ELIGIBILITY CRITERIA FOR SELECTING STUDIES: Blind randomized designs and controlled trials that reported the influence of CAF on HRV during exercise and during recovery from exercise, with strength of evidence assessed using the GRADE system; the search for the studies was organized using the PICOS strategy. RESULTS: A total of 1797 articles were recognized, following the screening and eligibility stages, 9 studies continued to the final sample. Six studies reported that the combination of CAF supplementation with physical exercise exhibited higher HR when compared to the placebo group during post-exercise recovery; additionally, prolonged activation of sympathetic cardiac control and delayed parasympathetic reactivation following exercise was observed. However, three studies demonstrated no CAF influence when using similar doses. SUMMARY/CONCLUSION: This review observed equivocal results in HR and HRV recovery following exercise with the 
presence of CAF consumption. These findings cannot confirm the cardiac autonomic changes observed where entirely due to the influence of CAF, and further studies should be performed to better understand this relationship.

Keywords: Autonomic nervous system; Caffeine; Cardiovascular physiology; Cardiovascular system; Exercise. 


\section{INTRODUCTION}

Caffeine (CAF) is one of the most widely utilized supplements in sports $^{1}$, and can be consumed in a variety of forms (e.g., energy drinks, coffee, etc.). The isolated form of CAF is classified as a methylxanthine, which can be quickly absorbed through the gastrointestinal tract and freely pass through the blood brain barrier ${ }^{2}$. In as early as $15-45$ minutes, elevated systemic levels of CAF are observed with peak concentrations occurring within the hour. According to the international society of sports nutrition position stand on CAF, consumption enhances aerobic performance, high-intensity exercise performance, and mental vigilance ${ }^{2}$. It is this relationship to CAF consumption that has led its wide acceptance amongst consumers as a strategy to improve their physical performance ${ }^{3-11}$.

Recommended doses of CAF are widely variable ${ }^{12}$, but can be best classified into three groups; low (up to $3 \mathrm{mg} / \mathrm{kg}$ ), moderate (between 5 and $6 \mathrm{mg} / \mathrm{kg}$ ) and high $\left(9 \mathrm{mg} / \mathrm{kg}\right.$ ) dosage ${ }^{13}$. The Food Drugs and Administration (FDA) states that CAF intake up to $400 \mathrm{mg} /$ day $(\sim 5 \mathrm{mg} / \mathrm{kg})$ is not associated with adverse health effects ${ }^{14}$; however, excessive doses of CAF consumption have shown acute symptoms such as anxiety, headaches and restlessness ${ }^{15,16}$, as well as increased risk of hypertension and cardiovascular disease. ${ }^{16,17}$ Furthermore, dosages of $9 \mathrm{mg} / \mathrm{kg}$ and $13 \mathrm{mg} / \mathrm{kg}$ did not cause significant differences in exercise performance when compared to $5 \mathrm{mg} / \mathrm{kg}$ dosage ${ }^{18}$, suggesting higher doses of CAF are unnecessary.

The manner in which CAF influences cardiovascular function is through the obstruction of adenosine receptors (A1 and A2) and activation of the sympathetic autonomic nervous system through the increased release of catecholamines in blood plasma ${ }^{19}$. These functions then result in tachycardia ${ }^{9}$ and increased time to muscular fatigue ${ }^{10}$. Though seemingly innocuous, these alterations were believed to be related to elevated risks of arrhythmias ${ }^{20}$. A study by Magkos et al. ${ }^{21}$ emphasized that the physiological changes triggered by the combination of CAF and exercise may be unfavorable without familiarity of cardiovascular parameters and the individuals' characteristics. These findings suggest that depending on physical activity 
intensity, CAF may become a contributing factor for harmful cardiovascular complications following exercise ${ }^{22}$. However, the majority of literature is in near agreement that moderate doses of CAF do not increase risk of untoward cardiac events ${ }^{23,24}$. Furthermore, an earlier study assessed patients with high risk for ventricular arrhythmias and heart failure who acutely consumed $500 \mathrm{mg}(\sim 6 \mathrm{mg} / \mathrm{kg})$ of CAF and completed a treadmill test. As a main outcome, the authors reported that $\mathrm{CAF}$ increased peak systolic and diastolic blood pressure during exercise, but was unable to induce arrhythmias. In agreement to this, several studies have found that alterations as the result of moderate $\mathrm{CAF}$ ingestion are trivial and do not appear to enhance risk to arrhythmia ${ }^{23,24}$.

The vast majority of studies that have examined $\mathrm{CAF}$ and cardiovascular function evaluated heart rate (HR) and electrocardiograms (ECG) for presence of arrhythmias. To this point, a key aspect of cardiovascular function through control of the autonomic nervous system (ANS) may have been overlooked. The ANS plays a key role in controlling blood pressure and $\mathrm{HR}^{25}$ and can be measured through $\mathrm{HR}$ variability (HRV), which is a non-invasive technique that assesses autonomic regulation of heart rhythm ${ }^{26} . \mathrm{HRV}$ is one of the most practical approaches to analyze the ANS function, both under pathological and normal physiological conditions $^{26}$. This method assesses the inter beat intervals (RR-intervals) oscillations, providing information about the parasympathetic and sympathetic influence on the sinus node ${ }^{27}$. Importantly, HRV provides a different metric by which cardiovascular function may be enhanced or inhibited, independent of changes in HR or the presence of arrhythmias ${ }^{27}$.

In this manner, we posed the following question: What is the influence of a CAF supplement before exercise on HR autonomic control? Evidence concerning the effects of CAF on HRV may contribute to the planning of novel strategies regarding the CAF consumption in order to prevent cardiovascular complications after exercise. Thus, we aimed to evaluate the influence of CAF in combination with physical exercise on HR and HRV. 


\section{METHODS}

This review was described through a systematized search, during the months of January at August 2019, founded on articles published and available in of MEDLINE, EMBASE and CINAHL. The review was achieved according to the protocol Preferred Reporting Items for Systematic Reviews and Meta-Analyzes (PRISMA) ${ }^{28}$ and the protocol for this review was published on PROSPERO (Protocol registration number PROSPERO CRD42019126347).

\section{Search strategy}

The identification of the articles was completed via the keywords obtained by the Medical Subject Headings (MeSH), which is the National Library of Medicine controlled vocabulary thesaurus used for indexing articles for PubMed. The research and selection of the studies were organized using the Population Intervention Comparison Outcome Study Design (PICOS) strategy. In this model, the search strategy was defined according to Population (P), Intervention (I), Control (C), Outcomes (O) and Study Design (S), with Mesh allocated in each category according to its search characteristic, with the purpose of optimizing the search: P - Healthy subjects, I - Caffeine and Exercise, C - Placebo and Exercise, O - Heart rate variability and heart rate, $\mathrm{S}$ - Randomized trials, single and double blind, crossover and controlled designs.

The following search terms were applied: “Autonomic Nervous System” OR "Heart Rate Variability" OR "Sympathetic Nervous System" OR "Parasympathetic Nervous System” OR "Autonomic Dysfunction" OR "Vagal Nerve" AND "Caffeine" AND "Exercise" in the titles and/or in the abstracts. After identifying the studies, the references were initially screened by applying the search criteria in the databases, using the following filters: studies undertaken in the past 10 years (2010 to 2019), free complete texts and use of English language.

The translocation of the identified studies in the databases for a matrix spreadsheet was commenced, where they were organized by numbering, database, author and year, title, journal, sample, main findings, conclusion and reason for exclusion; and this process signifies the beginning of the eligibility stage. In this procedure, the studies were subject to exclusion if they 
were unable to make an actual reference to the proposed revision theme, being evaluated by the title and abstract. Next, studies that did not have the relevant credentials to be excepted were read in their entirety. An inclusion criteria considered specific references to the proposed theme of the review and demonstration in methods section a technique to measure HRV, including electrocardiogram (ECG) or HR monitors with appropriate scientific validation (Polarß, Kempele, Finland; Models: V800 ${ }^{29}, \mathrm{RS} 800^{30}, \mathrm{~S} 810 \mathrm{i}^{31}$ ).

The final stage of selection for inclusion of the articles was performed by reading the complete articles, which was undertaken by two independent researchers. If there was a disagreement about the inclusion of a particular article, another additional reviewer was consulted for a final decision (once). Studies concluded this entire review process and, if the researchers decision was to be included, were assigned to a table with the subsequent information extracted: Author and Year. Sample, HRV Indices, Dosage and Main Conclusion, due to the order they were found in the databases.

\section{Data analysis}

The Grades of Recommendation, Assessment, Development, and Evaluation (GRADE) Working Group (GRADE Working Group, 2004) ${ }^{32}$ was followed in order to analysis the strength of evidence, including study design, broadly categorized as observational studies (low evidence) and randomized trials (high evidence). Study quality (detailed study methods and execution) and significant limitations secondarily were considered in strength of evidence analysis.

\section{Study eligibility criteria}

\section{Patients (subjects)}

We included studies with healthy physically active human adults (between 18 to 50 years old) and athletes. We excluded studies that enrolled individuals with cardiorespiratory, neurological, musculoskeletal, renal, metabolic, endocrine and other reported impairments that circumvented the acceptable performance of the physical exercise procedures. We standardized 
this inclusion and exclusion criteria in order to evaluate the CAF impact in trained subjects that use this compound for training and to facilitate physiological interpretation.

\section{Intervention}

The references nominated were based on CAF taken combined with exercise. CAF dose ranged between $100-500 \mathrm{mg}$ and between $2-5 \mathrm{mg} / \mathrm{kg}$, following recommendation from the FDA (up to $400 \mathrm{mg}$ ). We included studies that prescribed CAF in combination with another supplement (Citrus aurantium - 1mg/kg - and Taurine $-25 \mathrm{mg} / \mathrm{kg}$ ). Studies that used CAF combined with carbohydrates were excluded. No criteria were established for the form of physical exercise or sports modality in which the intervention with the CAF was proposed.

\section{Control}

We included references with the following placebo as controls: 1) dextrose capsule; 2) opaque gelatin capsule; 3) bottled mineral water with artificial refreshment; 4) starch capsule; 5) maltodextrin; 6) cellulose and; 7) flavor-matched.

\section{CAF Format}

We considered the following CAF format of supplementation: 1) Capsules and; 2) Energy drink.

\section{Outcome}

The principal outcome assessed was the linear indices of HRV: RMSSD (square root of the mean square of the differences between adjacent normal RR intervals), SDNN (standard deviation of all normal RR intervals), pNN50 (percentage of adjacent RR intervals with duration difference greater than 50 milliseconds), HF (high frequency), LF (low frequency), LF/HF ratio (Relation between low and high frequency components), SD1 (dispersion of points perpendicular to the identity line, instantaneous record of beat-to-beat variability), SD2 (scatter points along the identity line, long-term record). Secondary outcomes involved HR, HRmax (HR peak during exercise), DBP (diastolic blood pressure) and SBP (systolic blood pressure). 
This outcome was selected because they provide consistent information regarding cardiovascular and autonomic recovery following exercise.

\section{Study Design}

The references selected included randomized trials, single and double blind, crossover and controlled designs.

\section{Statistical Analysis}

Descriptive statistical analysis of the references are presented in mean \pm standard deviation. Among the nine references, four calculated effect size through Cohen's d or Eta squared.

\section{RESULTS}

The identification of the studies through search in the databases, MEDLINE, EMBASE and CINAHL resulted in 1797 articles referring to the appropriate cited terms. After sifting the articles through the screening steps, 161 articles were eligible to be read. After the eligibility stage only nine studies progressed to the final sample for this review. The search process and selection phases are illustrated in the Flow Diagram following the PRISMA protocol (Figure $1)$.

Description of the characteristics of the study population are presented in Table 1, while description of the selected articles by author and year, time ingestion CAF, CAF dose, placebo, analysis time, HRV index, main conclusions, strength of evidence and effect size through Cohen's $d$ is shown in Table 2.

Nelson et al. ${ }^{33}$ developed a study evaluating the effects of CAF in combination with physical exercise on HRV parameters in young adults $(25.5 \pm 4.1$ years old and body mass index (BMI) of $25.1 \pm 4 \mathrm{~kg} / \mathrm{m} 2)$. In their study, CAF $(2 \mathrm{mg} / \mathrm{kg})$ was presented via an energy drink containing Taurine $(25 \mathrm{mg} / \mathrm{kg})$. The administration of about $198.2 \pm 1.4 \mathrm{mg}$ of CAF increased HRmax during the exercise (CAF: $145.4 \pm 4.8$ vs Placebo: $133.1 \pm 4.9$, Cohens'd= 
2.53, a large effect size). The authors detected that 60 minutes after exercise cessation, the CAF group maintained the highest HR levels (CAF: $82.8 \pm 1.9$ vs Placebo: $77.9 \pm 3.8$, Cohens'd=1.43, a large effect size). Although the participants who ingested the beverage exhibited an increase in resting HR, the HRV analysis revealed no changes when compared to the placebo group. In addition to the previously mentioned study, Kliszczewicz et al. ${ }^{34}$ proposed to evaluate the effects of $100 \mathrm{mg}$ of CAF in combination with $100 \mathrm{mg}$ of Citrus Aurantium $(\sim 1 \mathrm{mg} / \mathrm{kg})$. The evaluation was completed prior to physical exercise and displayed an increase in HR and sympathetic activity despite no observed changes in resting parasympathetic activity. Yet, cardiac autonomic modulation was unaffected during the recovery period after physical exercise. Conversely, the studies that prescribed CAF alone established consistent outcomes regarding the influence of $\mathrm{CAF}$ on autonomic cardiac modulation and cardiovascular parameters which is the main outcome of this review.

Bunsawat et al. ${ }^{35}$ prescribed $400 \mathrm{mg}(5 \mathrm{mg} / \mathrm{kg})$ of CAF in 18 healthy subjects $(26 \pm 1$ years of age and BMI: $23.9 \pm 0.8 \mathrm{~kg} / \mathrm{m} 2$ ). In the CAF group there was a delay of cardiac autonomic recovery in the post-exercise period ( $\mathrm{LF} / \mathrm{HF})$, also, it maintained high $\mathrm{BP}, \mathrm{DBP}$ and SBP values after the exercise termination. Gonzaga et al. ${ }^{36}$ supported their results and reported that CAF delayed RMSSD and SD1 recovery after exercise in physically active men., The ingestion of $300 \mathrm{mg}(\sim 4 \mathrm{mg} / \mathrm{kg})$ of CAF in 32 physically active men $(23.59 \pm 3.45$ years old and BMI: 24.40 $\pm 2.82 \mathrm{~kg} / \mathrm{m} 2$ ) delayed vagal recovery after submaximal aerobic exercise (RMSSD and SD1), and promoted the persistence of elevated levels of blood pressure ${ }^{36}$.

In addition, Gonzaga et al. ${ }^{37}$ also assessed the effects of $300 \mathrm{mg}(\sim 4 \mathrm{mg} / \mathrm{kg})$ CAF on HR autonomic recovery in two groups of healthy young men according to aerobic capacity (low VO2: $<42.46 \mathrm{ml} / \mathrm{kg} / \mathrm{min}$ vs. high (VO2: $>42.46 \mathrm{ml} / \mathrm{kg} / \mathrm{min}$ ). The low aerobic capacity group showed a delay in parasympathetic recovery after performing 30 minutes of submaximal aerobic exercise $(60 \% \mathrm{VO} 2 \mathrm{max})$. On treadmill test, these effects were observed taking into account the RMSSD, SD1 and SD2 indexes. 
Studies that achieved an adequate measurement of the HRV analysis during the recovery period and prescribed CAF alone exhibited promising outcomes in relation to recovery status of the cardiac autonomic activity. The two aforementioned studies evaluated the HRV indices for 30 minutes in the recovery period, which gives more credibility and reliability to the results. Alternatively, Lopes-Silva et al. ${ }^{38}$ evaluated 10 male Taekwondo athletes $(21 \pm 4$ years old, eutrophic and 9 years of experience) and Rolim et al. ${ }^{39}$ evaluated 21 physically active men (22.3 \pm 2.9 years old and BMI: $25.2 \pm 2.7 \mathrm{~kg} / \mathrm{m} 2$ ) and discovered different outcomes when taking CAF at concentrations of $5 \mathrm{mg} / \mathrm{kg}(355 \pm 64.5 \mathrm{mg})$ and $3 \mathrm{mg} / \mathrm{kg}$, respectively. In the Lopes-Silva et al. ${ }^{37}$ study, the CAF was unable to provoke a delay in vagal reactivation and, for the Rolim et al. ${ }^{38}$ study, the parasympathetic regulation was revealed to be high compared to the placebo group. However, they performed an ultra-short-term recovery analysis, which persisted for 300 and 360 seconds, respectively, which probably led the two studies to achieve different results to those reported in the research literature.

The other four studies included in the review did not perform HRV analysis. Only the HR was evaluated. The study conducted by Smirmaul et al. ${ }^{40}$ comprised of seven physically active men $(29 \pm 6$ years old and eutrophic) who ingested $4 \mathrm{mg} / \mathrm{kg}(300 \pm 32 \mathrm{mg})$ of CAF prior to training in high intensity cycling. The HRmax of the CAF group presented statistically higher values (CAF: $185 \pm 6$ bpm vs. Placebo: $179 \pm 7 \mathrm{bpm}, \mathrm{p}=0.006)$. We computed an effect size, which provided Cohen's $\mathrm{d}=0.92$; which is a large effect size. Glaister et al. ${ }^{41}$ involved 16 male triathletes ( $38 \pm 8$ years old) accustomed to consuming a daily average of $225 \pm 135 \mathrm{mg}$ of CAF and who covered an average distance of $221 \pm 65 \mathrm{~km}$ per week. After the ingestion of $5 \mathrm{mg} / \mathrm{kg}$ $(383 \pm 39 \mathrm{mg})$ of CAF, the participants were evaluated prior to exercise and after performing physical exercise on an ergometric bicycle. The CAF reduced the resting HR (CAF: $59.5 \pm 8.1$ bpm vs Placebo $63.0 \pm 7.8$ bpm, Cohen's d=0.44, a small effect size) and did not influence HR 30 minutes after physical exercise (CAF: 70.8 bpm \pm 9 vs. $72.2 \pm 10.5$ bpm, Cohen's d=0.14, a very small effect size). 


\section{DISCUSSION}

This review set out to investigate the consequences of CAF on HR and HRV following exercise. Among the nine studies evaluated, six reported that deviations in HRV are dependent on the combination of three main factors: CAF dosage, type of exercise, and cardiorespiratory fitness. In regards to HR induced changes by CAF in exercise, we observed the following: 1) increased HR during exercise and throughout the recovery period; 2) prolonged post exercise sympathetic activity; 3) and delayed vagal reactivation. These effects can be greatly attributed to an increase in catecholamine release into the bloodstream prompted by $\mathrm{CAF}^{42}$. Nonetheless, three references did not support this assumption..$^{34,35,37}$ In order to provide specific details concerning the influence of CAF on recovery from exercise, we divided Discussion section in topics related to HR, HRV indices and CAF dosage.

\section{CAF and HR}

The most extensively measured variable evaluated in this review was HR. It was observed that the majority of studies indicated that CAF has the capacity to influence HR before, during, and following exercise ${ }^{33-41}$, though responses appeared to vary. The least represented period measured for HR was during the resting phase (i.e., ingestion period). Of the studies that were evaluated, all reported values for resting HR. Of them, only four reported HR following the consumption of CAF or CAF supplement ${ }^{33,34,36,41}$. Glaister et al.$^{41}$ found a decrease in HR in the group that took $5 \mathrm{mg} / \mathrm{kg}$ of CAF (CAF: $59.5 \pm 8.1 \mathrm{bpm}$ vs. Placebo: $63 \pm 7.8 \mathrm{bpm}$ ). The study performed by Gonzaga et $a l .{ }^{35}$ found no significant differences in HR between CAF supplementation or placebo protocols. Conversely, Nelson et al. ${ }^{33}$, found that there was an increase in resting $\mathrm{HR}$ in the group that ingested CAF compared to placebo following its ingestion, though the exact change was not reported. Lastly, when evaluating a CAF complex, Kliszczewicz et al. ${ }^{34}$ found that resting HR increased 45-minutes following its consumption $(59.7 \pm 7.93$ to $64.6 \pm 9.13 \mathrm{bpm})$. It is important to note that the studies selected for this review 
included an exercise bout or trial, which may have elicited an emotional response that resulted in an elevated resting HR. Future studies should implement emotional based scales to better understand this relationship.

During periods of exercise CAF appears to have equivocal effects on HR. Smirmaul et al. ${ }^{40}$ reported that the effect of CAF was able to increase HR during cycling exercise in both the isotime and time to exhaustion trials when compared to placebo. The authors suggested that differences in peak HR were not related to exercise performance, but rather the effect of the CAF supplement. Bunsawat et al. ${ }^{35}$ showed a modest, yet significant difference in the observed HRmax (189 \pm 2 bpm vs $192 \pm 2 \mathrm{bpm})$ in the CAF group during a maximal treadmill bout. Lopes-Silva et al. ${ }^{38}$ observed higher mean HR during three rounds of a Taekwondo protocol: Round 1) CAF: $170 \pm 8$ bpm vs. Placebo: $167 \pm 13$ bpm; Round 2) CAF: $175 \pm 6$ bpm vs. Placebo: $173 \pm 10$ bpm; Round 3) CAF: $178 \pm 6$ bpm vs. Placebo: $177 \pm 10$ bpm, but were not enough to be significantly different. In contrast to the aforementioned increases in peak HR, Glaister et al. $^{41}$ found that at rest and during the early stages of an incremental cycle test, the CAF trial demonstrated lower HR; however, this relationship was lost at higher levels of exercise intensity. Supporting this was Gonzaga et al. ${ }^{36}$, Nelson et al. ${ }^{33}$ and Kliszczewicz et al..$^{34}$ whom found no differences in peak HRs between CAF and Placebos. In the studies that failed to demonstrate peak differences, two performed exercise bouts that where considered submaximal, which may have failed to elicit enough of a cardiovascular stress to elicit differences in peak HR. Conversely, the other two studies were considered to be maximal effort exercises and therefore may have induced maximal obtainable peaks in both trials. In all, it would appear that the supplementation of CAF results in an increased HR during high-intensity exercise bouts that are shy of maximal intensity.

Five of the reviewed studies examined HR during the recovery periods following exercise. Bunsawat et al. ${ }^{35}$ and Lopes-Silva et al. ${ }^{38}$ observed similar delays in heart return during early phases of recovery when compared to placebo controls. However, Gonzaga et al. ${ }^{36}$, Glaister et 
al. ${ }^{41}$ and Kliszczewicz et al. ${ }^{34}$ found no differences between CAF and placebo protocols regarding HR during recovery from exercise. Some of the differences observed may be due to the exercise intensity, which the protocols of Bunsawat et al. ${ }^{35}$, Lopes-Silva et al. ${ }^{38}$ and Kliszczewicz et al. ${ }^{34}$ were all considered to be of high-intensity. Interestingly, Kliszczewicz et al. ${ }^{34}$ was the only one to demonstrate no changes in post exercise HR, which may be due to the dosage of CAF used in the protocol, which was 2-4 times less than that used in the Bunsawat et al. ${ }^{35}$ and Lopes-Silva et al. ${ }^{38}$ studies. Though there is limited information, it would appear that higher dosages of CAF in conjunction to higher intensity exercise may cause a delayed rebound in HR.

\section{CAF and HRV}

The prolonged delay of autonomic recovery following exercise is associated with higher cardiovascular risk ${ }^{43}$, and therefore the focus of many applied and clinical intervention studies $^{44}$. A pragmatic technique to assess the efficiency of a given intervention is the evaluation of HRV pre-exercise and subsequent rebound post-exercise ${ }^{45}$. Though HRV and exercise alone have been widely evaluated, relatively little information regarding CAF supplementation on resting and recovering HRV status exists. Amongst the nine studies presented in this review, seven examined indices of HRV, with five examining resting ${ }^{33-38}$, and six examining recovery ${ }^{34-}$ 36,37-39. The findings of these studies are equivocal and therefore inconclusive, further points of consideration are provided below.

Similar to the HR markers evaluated in this review, resting HRV was the least represented. Though six of the papers measured resting values, Bunsawat et al. ${ }^{35}$ only reported HRV prior to supplement consumption, and therefore did not provide insight into the influence of CAF over resting values. Rolim et al. ${ }^{39}$, Gonzaga et al. ${ }^{36}$, Kliszczewicz et al. ${ }^{34}$ and Gonzaga et al. ${ }^{37}$ all found no changes in resting markers of parasympathetic activity following the consumption of CAF or CAF complex. These findings are in accordance to several studies that have evaluated the ingestion of CAF at rest. However, it was noted that sympathetic activity was 
increased in Kliszczewicz et al. ${ }^{34}$ with plasma catecholamines and LF being elevated independent of a static vagal activity. In contrast, Nelson et al. ${ }^{33}$ observed a vagal withdrawal one hour following the consumption of CAF when compared to the PLA group; however, direct changes from pre consumption to post consumption was not measured. The findings of this review suggest that there is little to no influence of CAF on markers of HRV. It is important to note that the majority of the studies compare post values to establish a difference between the supplement and PLA and therefore change relative to the condition may be lost. Future research should include pre and post consumption values to better assess the influence of CAF on HRV, especially in protocols involving exercise.

A primary purpose of this review was to evaluate the influence of CAF on the rebound of HRV following exercise, overall the findings yielded conflicting results. Rolim et al. ${ }^{39}$ found that CAF triggered an accelerated vagal reactivation following a sub-maximal treadmill bout. This enhanced recovery should perhaps stand alone in the findings because they compared the HRV indices (SD1 and SD2) for only the first 3 minutes, whereas more commonly used indices (RMSSD, HF and LF) discard the first five minutes of the recording prior to analysis. The findings of Kliszczewicz et al. ${ }^{34}$ indicated that CAF did not influence cardiac autonomic recovery following a repeated Wingate protocol when compared to placebo. Similarly, Nelson et al. ${ }^{33}$ revealed that CAF in combination with taurine did not significantly change the linear time domain and frequency HRV indices when compared to placebo protocol. Bunsawat et al. ${ }^{35}$ undertook a more comprehensive analysis during the 30 -minute recovery period following a maximal exercise protocol; and evaluated several cardiac autonomic markers (HR, BP and HRV). It was reported that in the CAF trial delayed adjustments in the autonomic recovery via $\mathrm{HR}$ and BP; however, in regards to HRV only LF/HF indexes demonstrated this inhibited recovery. In agreement with the inferences made by Bunsawat et al. ${ }^{35}$, Gonzaga et al..$^{36}$ and Gonzaga et al. ${ }^{37}$ reported that CAF delayed RMSSD during early stages of recovery following aerobic moderate exercise in healthy physical active men. 
An additional consideration to these findings is cardiorespiratory fitness, which as a variable may relate to the influence of CAF on parasympathetic recovery after exercise. Gonzaga et al. ${ }^{37}$ identified a delay in the recovery of the RMSSD, SD1 and SD2 indices in the low aerobic capacity group $\left(\mathrm{VO}_{2} 34.69 \pm 6.92 \mathrm{~mL} / \mathrm{kg} / \mathrm{min}\right)$. These indices were evaluated over one hour after exercise and showed significant differences in recovery time compared to the high aerobic capacity group $\left(\mathrm{VO}_{2} 53.32 \pm 8.79 \mathrm{~mL} / \mathrm{kg} / \mathrm{min}\right)$. Though this presents an appealing covariant to the relation of CAF and vagal rebound, further evidence is needed to establish this relationship.

The abovementioned references ${ }^{33-36}$ examined HRV, at minimum, during the initial 30 minutes of recovery following exercise. We highlight that longer lasting analysis throughout the recovery period provides a more detailed identification of adjustments in cardiac activity ${ }^{43}$. Therefore, the assessment of recovery for a period greater than 30 minutes following exercise would be more reliable for interpretation of relevant outcome measures. Due to the inconsistent findings of this review no viable inferences can be made in regards to the influence of CAF on recovery. However, what can be determined is the need for further research to provide much needed insight into the conditions that may or may not influence the recovery of HRV.

\section{CAF Dosage}

CAF influences the cardiovascular system by acting as an inhibitor of monoamine oxidase, which induces increased levels of epinephrine, norepinephrine, serotonin and dopamine ${ }^{44}$. Due to this function, CAF should be capable of evoking tachycardic and pressor responses related higher sympathetic activity via beta adrenergic receptor activation in the heart sinoatrial node and alpha-1 adrenergic receptors in the systemic vasculature ${ }^{36-37}$. Moreover, CAF is also a ryanodine receptors agonist, which acts upon the sarcoplasmic reticulum, helping a $\mathrm{Ca} 2+-$ specific channel ${ }^{45}$, thereby increasing contractility ${ }^{46}$. The magnitude of these effects appears to be influenced by dose. Studies have shown that small doses of CAF cause significant changes in the modulation of cardiac activity ${ }^{34}$. However, the effects of CAF appear to be nonlinear with 
increasing dosage, demonstrating diminishing returns at higher levels ${ }^{41}$. Within the included references of this review, different protocols and dosages of CAF supplementation were used (e.g., fixed values or relative to body weight). The dosages of CAF used were as follows: 100 $\mathrm{mg}(\sim 1 \mathrm{mg} / \mathrm{kg})^{34}, 300 \mathrm{mg}(\sim 4 \mathrm{mg} / \mathrm{kg})^{36,39}, 400 \mathrm{mg}(\sim 5 \mathrm{mg} / \mathrm{kg})^{35}, 2 \mathrm{mg} / \mathrm{kg}^{33}, 3 \mathrm{mg} / \mathrm{kg}^{39}, 4 \mathrm{mg} / \mathrm{kg}^{40}$, $5 \mathrm{mg} / \mathrm{kg}^{38,41}$.

Kliszczewicz et al. $^{34}$, evaluated subjects that participated in an exhaustive exercise protocol, which comprised of a one-minute warm-up period performed at $50 \mathrm{~W}$ with a rolling start into the Wingate test, with a 30-s duration. The volunteers were encouraged to pedal at their maximal effort against a resistance of $0.80 \mathrm{Nm} / \mathrm{kg}$. The authors noted that $\sim 1 \mathrm{mg} / \mathrm{kg}$ CAF combined with the Citrus Aurantium $(\sim 1 \mathrm{mg} / \mathrm{kg})$ increased sympathetic control without influencing the parasympathetic recovery following effort. Supporting their findings, Gonzaga et al. ${ }^{36}$ evaluated a dosage of $300 \mathrm{mg}(\sim 4 \mathrm{mg} / \mathrm{kg})$ of CAF before moderate aerobic exercise and observed diminished post-exercise ANS recovery. A slower return of RMSSD and SD1 indices were also detected.

Gonzaga et al. ${ }^{37}$ also demonstrated that the combination of CAF $300 \mathrm{mg}(\sim 4 \mathrm{mg} / \mathrm{kg})$ and submaximal aerobic exercise in people with low cardiorespiratory capacity resulted in delayed post-exercise vagal recovery. The RMSSD, SD1 and SD2 recovery showed significant differences compared to the high cardiorespiratory capacity group. In this case, the authors suggest sedentary subjects who take CAF before exercise should adhere to the dosage proposed by the FDA, in order to reduce the possibility of cardiovascular complications.

In Lopes-Silva et $\mathrm{al}^{38}$, the group that consumed CAF $(5 \mathrm{mg} / \mathrm{kg}, \sim 300 \mathrm{mg}$ to $400 \mathrm{mg})$ consistently presented a higher HR when compared to control, but no changes in RMSSD was reported. However, this result may be related to the training experience of the participants (minimum 9 years). No statistical differences were observed between groups during the first 150 seconds of recovery after the last session; however, the CAF group demonstrated a 
constant, yet non-significant of heightened HR between 180 and 360 seconds after exercise cessation.

Nelson et al. ${ }^{33}$ evaluated the supplementation of CAF $2 \mathrm{mg} / \mathrm{kg}$ (around 120 and $160 \mathrm{mg}$ ) in combination with Taurine $25 \mathrm{mg} / \mathrm{kg}$ prior to an aerobic exercise protocol. The only variable to demonstrate significant changes was HR, while no significant variation was observed in indices of HRV when compared to the placebo group. Energy drinks are difficult to evaluate in regards to the influence of CAF on exercise performance and physiological responses due to several ingredients and dosages.

In summary, the studies that reported significant influence of CAF on cardiovascular variables or HRV used $\sim 1 \mathrm{mg} / \mathrm{kg}^{34}, 2 \mathrm{mg} / \mathrm{kg}^{33}, \sim 4 \mathrm{mg} / \mathrm{kg}^{36,37}, 4 \mathrm{mg} / \mathrm{kg}^{40}$, and $\sim 5 \mathrm{mg} / \mathrm{kg}^{35}$ dosages, while no CAF effects were noted with $3 \mathrm{mg} / \mathrm{kg}^{39}$ and doses of $5 \mathrm{mg} / \mathrm{kg}^{38,41}$. In this scenario, we observe that there are equivocal results using similar doses. These findings raise the question: What is the most effective and safe dose of CAF is for exercise and cardiovascular health? The studies evaluated in this review do not totally support that CAF delays HRV recovery from exercise, though they did demonstrate alterations in autonomic control. Therefore, we suggest relative caution for people who plan to begin a physical exercise training and the use higher doses CAF. A medical consult and detailed physical examination is recommended before exercise initiation.

\section{CAF combined with supplements}

Two studies evaluated the effects of CAF combined with other supplements. Kliszczewicz et al. ${ }^{34}$, analyzed CAF combined with the Citrus Aurantium, they evidenced that this combination increased resting sympathetic control of heart rhythm but did not influence the parasympathetic HR recovery following exercise. Citrus Aurantium is extracted from the orange and contains the active ingredient of p-synephrine, a sympathomimetic protoalkaloid. It has been indicated as a mild central nervous system stimulant ${ }^{47}$; however, p-synephrine acts on beta-3 receptors on adipose tissue and do not exhibit any action on the heart. In this line, we 
hypothesize that p-synephrine has a minimal effect of CAF. However, there is no previous study that evaluate the impact of Citrus Aurantium on cardiovascular and autonomic nervous systems during recovery from exercise.

Nelson et al. ${ }^{33}$ investigated CAF in combination with Taurine before exercise. There was no significant change in HRV compared to placebo. The authors theorized that Taurine would attenuate the CAF stimulus on ANS. This proposition is supported by Rakmanee et al. ${ }^{48}$, which evaluated the effects of taurine on autonomic nervous system in adult male rats. As a main finding, they reported that taurine supplementation decreased sympathetic renal nerve activity in animals with high sugar diet. Yet, there is a lack of conclusive evidence and more controlled studies needed to achieve an improved outcome.

Taken together, the studies supported that taurine may attenuate the sympathetic activation and parasympathetic withdrawal caused by $\mathrm{CAF}$, whereas Citrus Aurantium combined with CAF has no significant influence on HRV recovery.

\section{Points to be addressed}

Some points of consideration are worth highlighting regarding the studies selected for this review. Only one study used CAF as an energy drink (CAF combined with taurine $)^{33}$, which demonstrated increased resting HR and no influence over HRV following exercise. The others investigated CAF in the form of capsules and pills. We believe that the mechanism of CAF supplementation may influence HRV recovery following exercise, since vagal activation induced by stomach volume changes may affect parasympathetic activity. These vehicles for supplementation should be further evaluated.

Alternative types of physical exercise were applied in combination with CAF, the modalities or equipment necessary to accomplish the tests were: Treadmil1 ${ }^{35,36,37,39}$; Ergometric Bicycle $^{33,34,40,41}$ and Fight ${ }^{38}$. Additionally, markers of ANS activity evaluated in this literature review differed in collection technique, timing, and indices, thus providing some variation in the interpretations. The references selected exposed differences between participants and, we 
hypothesize that the greater the experience with physical activity, the better adaptation of the ANS to CAF.

Taken together, we cite attention for more consideration to the effects of CAF ingestion before physical exercise and the possible deleterious effects on cardiovascular health of this grouping. Furthermore, we recommend more comprehensive evaluation of ANS activity during CAF supplementation through the ingestion and recovery periods. We recommend the individual concerned prescribing CAF as a supplement to seek clinical medical advice.

\section{CONCLUSIONS}

Among the nine references evaluated, six evidenced that CAF delays cardiovascular and autonomic recovery following aerobic exercise, whereas three showed opposite results even with similar dosage. This review proposes that the effects of CAF in delaying HR and HRV on post-aerobic exercise recovery is still not totally supported by the current literature. Even though, we stress the importance of clinical and specific evaluation of individuals who intend to use $\mathrm{CAF}$ as a supplement before exercise, so as to evade possible harmful cardiovascular difficulties. 


\section{REFERENCES}

1. Turnbull D, Rodricks JV, Mariano GF, Chowdhury F. Caffeine and cardiovascular health. Regul Toxicol Pharmacol 2017;89:165-185. https://doi.org/10.1016/j.yrtph.2017.07.025.

2. Goldstein ER, Ziegenfuss T, Kalman D, Kreider R, Campbell B, Wilborn C. et al. International society of sports nutrition position stand: caffeine and performance. J Int Soc Sports Nutr 2010;7(1):5. https://doi.org/10.1186/1550-2783-7-5

3. Lopéz-González LM, Sánchez-Oliver AJ, Mata F, Jodra P, Antonio J, Domínguez R. Acute caffeine supplementation in combat sports. J Int Soc Sports Nutr 2018;15(60):01-11. https://doi.org/10.1186/s12970-018-0267-2

4. Cappelletti S, Daria P, Sani G, Aromatario M. Caffeine: Cognitive and physical performance enhancer or psychoactive drug?. Curr Neuropharmacol 2015;13(1):71-88. https://doi.org/10.2174/1570159X13666141210215655

5. Gonçalves LS, Painelli VS, Yamaguchi G, Oliveira LF, Saunders B, Silva R P et al. Dispelling the myth that habitual caffeine consumption influences the performance response to acute caffeine supplementation. J Appl Physiol 2017;123(1):213-220. https://doi.org/10.1152/japplphysiol.00260.2017

6. Southward K, Rutherfurd-Markwick KJ, Ali A. The effect of acute caffeine ingestion on endurance performance: A systematic review and meta-analysis. Sports Med 2018;48(8):1913-1928. https://doi.org/10.1007/s40279-018-0939-8

7. França VF, Malfatti CRM, Silva AL, Wietzikoski EC, Osiecki A, Osiecki R. Effect of acute caffeine supplementation on biochemical response during endurance exercise in rats. Rev Bras Med Esp 2015;21(5):372-375. https://doi.org/ 10.1590/1517-869220152105109981

8. Tarnopolsky MA. Caffeine and Creatine use in Sport. Ann Nutr Metab 2010;57(2):01-08. https://doi.org/10.1159/000322696

9. De Sanctis V, Soliman N, Soliman AT, Elsedfy H, Di Maio S, El Kholy M. et al. Caffeinated energy drink consumption among adolescents and potential health consequences associated with their use: a significant public health hazard. Acta Biomed 
2017;88(2):222-231. https://doi.org/10.23750/abm.v88i2.6664

10. Lozeski ECS, Smolarek A, Silva AL, Martins FAZ, Malfatti CRM, Martins JCL. Caffeine supplementation and its relationship with increased muscle strength: an integrative review. Rev Bras Nut Esp 2018;12(72):786-795.

11. Moura DP, Lavor E, Silva LAR. Acute effect of caffeine in strength training. Rev Bras Nut Esp 2017;11(67):891-897.

12. McLellan TM, Caldwell JA, Lieberman HR. A review of caffeine's effects on cognitive, physical and occupational performance. Neuroscience \& Biobehavioral Reviews 2016;71:294-312. https://doi.org/10.1016/j.neubiorev.2016.09.001

13. Spriet LL. Exercise and sport performance with low doses of caffeine. Sports Med 2014;44(2):175-184.

14. Mitchell DC, Knight CA, Hockenberry J, Teplansky R, Hartman TJ. Beverage caffeine intakes in the U.S. Food Chem Toxicol 2014;63:136-142.

15. Nawrot P, Jordan S, Eastwood J, Rostein J, Hugenholtz A, Feeley M. Effects of caffeine on human health. Food Addit Contam. 2003; 20(1):1-30. https://doi.org/10.1080/0265203021000007840

16. Heckman MA, Weil J, Gonzalez de Meija E. Caffeine (1, 3, 7-trimethylxanthine) in foods: a comprehensive review on consumption, functionality, safety, and regulatory matters. $\mathrm{J}$ Food Sci. 2010;75(3):77-87. https://doi.org/10.1111/j.1750-3841.2010.01561.X

17. Nurminen ML, Niittynen L, Korpela R, Vapaatalo H. Coffee, caffeine and blood pressure: a critical review. Eur J Clin Nutr. 1999;53(11)831-9.

18. Pasman W, Baak M, Jeukendrup A, Haan A. The effect of different dosages of caffeine on endurance performance time. Int J Sports Med 1995;16(4):225-230.

19. Schwabe U, Ukena D, Lohse MJ. Xanthine derivatives as antagonists at A1 and A2 adenosine receptors. Naunyn Schmiedebergs Arch Pharmacol 1985;330(3):212-21.

20. Zuchinali P, Souza GC, Pimentel M, Chemello D, Zimerman A, Giaretta V. et al. Shortterm effects of high-dose caffeine on cardiac arrhythmias in patients with heart failure: A 
Randomized Clinical Trial. JAMA Intern Med 2016;176(12):1752-1759. https://doi.org/10.1001/jamainternmed.2016.6374

21. Magkos F, Kavouras SA. Caffeine and ephedrine: physiological, metabolic and performance-enhancing effects. Sports Med 2004;34(13):871-89. https://doi.org/10.2165/00007256-200434130-00002

22. Basrai M, Schweinlin A, Menzel J, Mielke H, Weikert C, Dusemund B. et al. Energy Drinks Induce Acute Cardiovascular and Metabolic Changes Pointing to Potential Risks for Young Adults: A Randomized Controlled Trial. J Nutr 2019;149(3):441-450. https://doi.org/10.1093/jn/nxy303

23. Klatsky AL, Hasan AS, Armstrong MA, Udaltsova N, Morton C. Coffee, caffeine, and risk of hospitalization for arrhythmias. Perm J 2011;15(3):19-25.

24. Chelsky LB, Cutler JE, Griffith K, Kron J, McClelland JH, McAnulty JH. Caffeine and ventricular arrhythmias. An electrophysiological approach. JAMA 1990;264(17):2236-40.

25. Ginty AT, Kraynak TE, Fisher JP, Gianaros PJ. Cardiovascular and autonomic reactivity to psychological stress: Neurophysiological substrates and links to cardiovascular disease. Auton Neurosci 2017;207:2-9. https://doi.org/10.1016/j.autneu.2017.03.003

26. Camm AJ, Malik M, Bigger JT, Breithardt G, Cerutti S, Cohen RJ. et al. Heart rrate variability: standards of measurement, physiological interpretation and clinical use. Task Force of the European Society of Cardiology and the North American Society of Pacing and Electrophysiology. Circulation 1996;93(5):1043:65.

27. Nolan RP, Jong P, Barry-Bianchi SM, Tanaka TH, Floras JS. Effects of drug, biobehavioral and exercise therapies on heart rate variability in coronary artery disease: a systematic review. Eur J Cardiovasc Prev Rehabil 2008;15(4):386-96. https://doi.org/10.1097/HJR.0b013e3283030a97

28. Moher D, Liberati A, Tetzlaff J, Altman DG; Prisma Group. Preferred reporting items for systematic reviews and meta-analyses: the PRISMA statement. PLoS Medicine 2009;6(7):01-06. https://doi.org/10.1371/journal.pmed.1000097 
29. Giles D, Draper N, Neil W. Validity of the Polar V800 heart rate monitor to measure RR intervals at rest. Eur J Appl Physiol 2016;116(3):563-71. https://doi.org/10.1007/s00421$\underline{015-3303-9}$

30. Barbosa MP, da Silva NT, de Azevedo FM, Pastre CM, Vanderlei LC. Comparison of Polar ${ }^{\circledR}$ RS800G3 ${ }^{\text {TM }}$ heart rate monitor with Polar ${ }^{\circledR}$ S810i ${ }^{\text {TM }}$ and electrocardiogram to obtain the series of RR intervals and analysis of heart rate variability at rest. Clin Physiol Funct Imaging 2016;36(2):112-7. https://doi.org/10.1111/cpf.12203

31. Vanderlei LC, Silva RA, Pastre CM, Azevedo FM, Godoy MF. Comparison of the Polar S810i monitor and the ECG for the analysis of heart rate variability in the time and frequency domains. Braz J Med Biol Res 2008;41(10):854-9. https://doi.org/

\section{$\underline{10.1590 / \mathrm{S} 0100-879 \times 2008005000039}$}

32. Atkins D, Best D, Briss PA, Eccles M, Falck-Ytter Y, Flottorp S. et al. GRADE Working Group. Grading quality of evidence and strength of recommendations. BMJ 2004;328(7454):1490. https://doi.org/10.1136/bmj.328.7454.1490

33. Nelson MT, Biltz GR, Dengel DR. Cardiovascular and ride time-to-exhaustion effects of an energy drink. J Int Soc Sports Nutr 2014,11(2):01-07. https://doi.org/10.1186/1550$\underline{2783-11-2}$

34. Kliszczewicz B, Bechke E, Williamson C, Bailey P, Hoffstetter W, McLester J. et al. The influence of citrus aurantium and caffeine complex versus placebo on the cardiac autonomic response: a double blind crossover design. J Int Soc Sports Nutr 2018;15(34):01-08. https://doi.org/10.1186/s12970-018-0240-0

35. Bunsawat K, Withe DW, Kappus RM, Baynard T. Caffeine delays autonomic recovery following acute exercise. Eur J Prev Cardiol 2015;22(11):1473-1479. https://doi.org/10.1177/2047487314554867 
36. Gonzaga LA, Vanderlei LCM, Gomes RL, Valenti VE. Caffeine affects autonomic control of heart rate and blood pressure recovery after aerobic exercise in Young adults: a crossover study. Sci Rep 2017;7(1):01-08. https://doi.org/10.1038/s41598-017-14540-4

37. Gonzaga LA, Vanderlei LCM, Gomes RL, Garner DM, Valenti VE. Involvement of cardiorespiratory capacity on the acute effects of caffeine on autonomic recovery. Medicina 2019;55(196):01-10. https://doi:10.3390/medicina55050196

38. Lopes-Silva JP, Silva Santos JF, Branco BH, Abad CC, Oliveira LF, Loturco I. et al. Caffeine ingestion increases estimated glycolytic metabolism during taekwondo combat simulation but does not improve performance or parasympathetic reactivation. PLoS One 2015;10(11):01- 16. https://doi.org/10.1371/journal.pone.0142078

39. Rolim PS, Matos RAC, Soares EMKKS, Molina GE, Cruz CJG. Caffeine increases parasympathetic reactivation without altering resting and exercise cardiac parasympathetic modulation: A balanced placebo desing. Eur J Sport Sci 2018;16:01-09. https://doi.org/10.1080/17461391.2018

40. Smirmaul BP, Moraes AC, Angius L, Marcora SM. Effects of caffeine on neuromuscular fatigue and performance during high-intensity cycling exercise in moderate hypoxia. Eur $\mathrm{J}$ Appl Physiol 2017;117(1):27-38. https://doi.org/10.1007/s00421-016-3496-6

41. Glaister M, Williams BH, Muniz-Pumares D, Balsalobre-Fernández C, Foley P. The effects of caffeine supplementation on physiological responses to submaximal exercise in endurance-trained men. PLoS One 2016;11(8):01-15. https://doi.org/10.1371/journal.pone.0161375

42. Turnbull D, Rodricks JV, Mariano GF, Chowdhury F. Caffeine and cardiovascular health. Regul Toxicol Pharmacol 2017;89:165-185. https://doi.org/10.1016/j.yrtph.2017.07.025

43. Peçanha T, Bartels R, Brito LC, Paula-Ribeiro M, Oliveira RS, Goldberger JJ. Methods of assessment of the post-exercise cardiac autonomic recovery: A methodological review. Int J Cardiol 2017;227:795-802. https://doi.org/10.1016/j.ijcard.2016.10.057 
44. Petzer A, Pienaar A, Petzer JP. The interactions of caffeine with monoamine oxidase. Life Sci 2013; 93:283-287. https://doi.org/10.1016/j.1fs.2013.06.020

45. Arnáiz-Cot JJ, Damon BJ, Zhang XH, Cleemann L, Yamaguchi N, Meissner G, Morad M. Cardiac calcium signalling pathologies associated with defective calmodulin regulation of type 2 ryanodine receptor. J Physiol 2013;591:4287-4299.

https://doi.org/10.1113/jphysiol.2013.256123

46. Pettersen SA, Krustrup P, Bendiksen M, Randers MB, Brito J, Bangsbo J, Jin Y, MohrM. Caffeine supplementation does not affect match activities and fatigue resistance during match play in young football players. J Sports Sci 2014;32:1958-1965. https://10.1080/02640414.2014.965189

47. Stohs SJ, Preuss HG, Shara M. A review of the receptor-binding properties of p-synephrine as related to its pharmacological effects. Oxid Med Cell Longev. 2011;2011:482973.

48. Rakmanee S, Kulthinee S, Wyss JM, Roysommuti S. Taurine Supplementation Reduces Renal Nerve Activity in Male Rats in which Renal Nerve Activity was Increased by a High Sugar Diet. Adv Exp Med Biol. 2017;975:27-37. 


\section{PRISMA 2009 Flow Diagram}
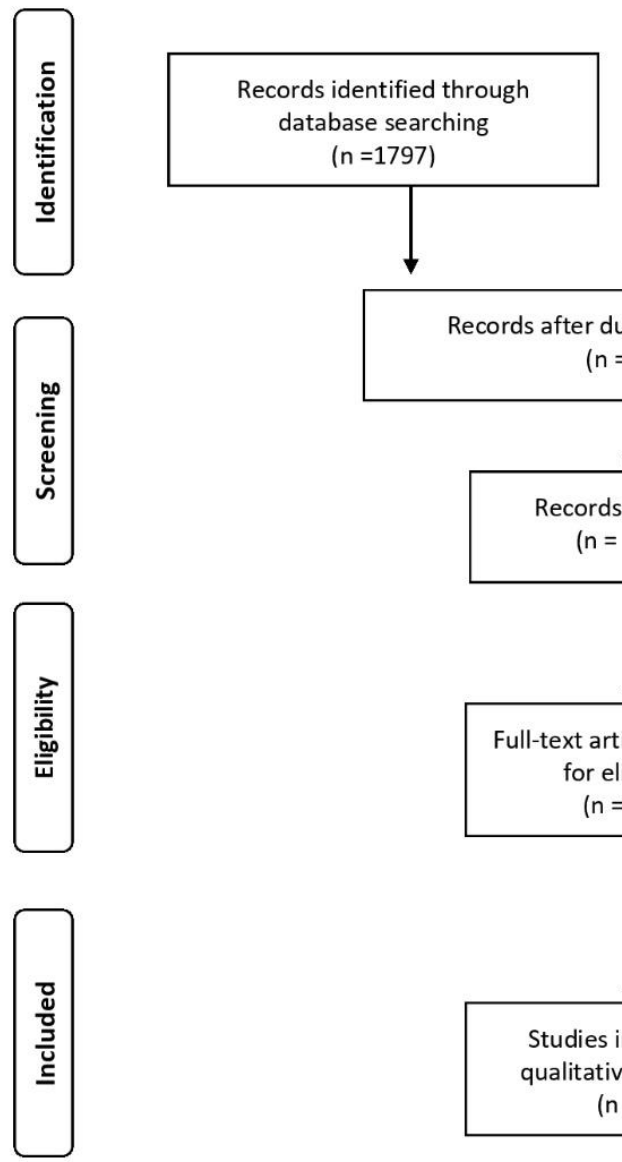

Additional records identified through other sources $(\mathrm{n}=1797)$ $(n=0)$

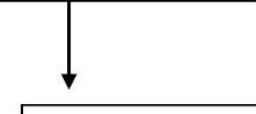

Records after duplicates removed $(n=271)$

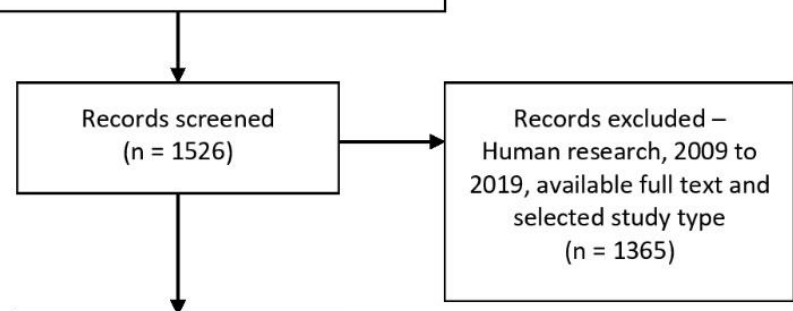

Full-text articles assessed for eligibility ( $n=161$ )

Full-text articles excluded used inadequate measurement methods ( $n=151$ ) inadequate study population $(n=1)$

Studies included in qualitative synthesis ( $n=9)$

Figure 1. Flowchart of search strategy and selection of studies. Preferred Reporting Items for Systematic Reviews and Meta-Analyses (PRISMA). ${ }^{17}$ 
Table 1. Description of the characteristics of the study population of articles by author and year, sample, age (years), weight (kg), height (cm), BMI $\left(\mathrm{kg} / \mathrm{m}^{2}\right)($ mean $\pm \mathrm{SD})$, exercise, average peak oxygen $(\mathrm{ml} / \mathrm{kg} / \mathrm{min})$, exercise intensity.

\begin{tabular}{|c|c|c|c|c|c|c|c|c|}
\hline Author/years & Sample & Age (years) & Weight (kg) & $\begin{array}{l}\text { Height } \\
\text { (cm) }\end{array}$ & $\begin{array}{c}\text { BMI } \\
\left(\mathbf{k g} / \mathbf{m}^{2}\right)\end{array}$ & Exercise & $\begin{array}{l}\text { Average Peak } \\
\text { Oxygen } \\
(\mathrm{ml} / \mathrm{kg} / \mathrm{min})\end{array}$ & Exercise Intensity \\
\hline
\end{tabular}

\begin{tabular}{|c|c|c|c|c|c|c|c|c|}
\hline $\begin{array}{l}\text { Kliszczewicz } \\
\text { et al. }{ }^{27}\end{array}$ & 14 healthy men & $25.1 \pm 3.9$ & $78.71 \pm 9.53$ & $177.2 \pm 4.6$ & - & $\begin{array}{l}\text { Ergometric } \\
\text { Bicycle }\end{array}$ & - & $\begin{array}{l}50 \text { and } 100 \mathrm{rpm} \text { at a } \\
\text { resistance of } 1.5 \mathrm{kp}\end{array}$ \\
\hline $\begin{array}{l}\text { Smirmaul et } \\
\text { al. }{ }^{33}\end{array}$ & $\begin{array}{l}7 \text { healthy and } \\
\text { active men }\end{array}$ & $29 \pm 6,0$ & $75 \pm 8,0$ & $179 \pm 8,0$ & - & $\begin{array}{l}\text { Ergometric } \\
\text { Bicycle }\end{array}$ & - & $\begin{array}{l}5 \text { minutes Breathing hypoxic } \\
\text { air, a heating cycle of } 3 \mathrm{~min} \\
\text { to } 40 \% \text { PPO, a fixed period } \\
\text { of } 6 \text { min (isotime) of cycling } \\
\text { exercise in hypoxia at } 78 \pm \\
3 \% \text { PPO.. }\end{array}$ \\
\hline
\end{tabular}

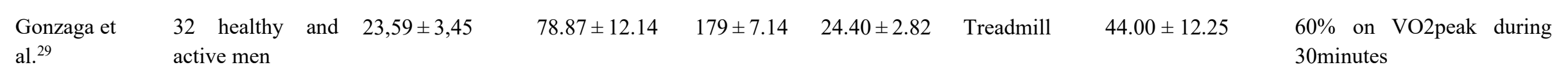

\begin{tabular}{|c|c|c|c|c|c|c|c|c|}
\hline $\begin{array}{l}\text { Bunsawat et } \\
\text { al. }{ }^{28}\end{array}$ & $\begin{array}{l}18 \text { healthy } \\
\text { individuals }\end{array}$ & $26 \pm 1,0$ & - & - & $23.9 \pm 0,8$ & Treadmill & - & $\begin{array}{lr}\begin{array}{l}\text { Maximum } \\
\text { consumption }\end{array} & \text { oxygen } \\
\text { followed by } 2 \text { max }),\end{array}$ \\
\hline
\end{tabular}




\begin{tabular}{|c|c|c|c|c|c|c|c|c|}
\hline & & & & & & & & $\begin{array}{l}\text { recovery at a speed of } \\
3.5 \mathrm{kmh} \text { and grade of } 0 \% .24\end{array}$ \\
\hline \multirow[t]{2}{*}{$\begin{array}{l}\text { Gonzaga et al. } \\
30\end{array}$} & \multirow[t]{2}{*}{$\begin{array}{l}32 \\
\text { subjects }\end{array}$} & \multirow[t]{2}{*}{$23.69 \pm 3.75$} & \multirow[t]{2}{*}{$78.38 \pm 6.92$} & \multirow[t]{2}{*}{$180 \pm 4.0$} & \multirow[t]{2}{*}{$24.33 \pm 2.04$} & \multirow[t]{2}{*}{ Treadmill } & $\begin{array}{l}\text { Group: High } \mathrm{VO}_{2}: \\
53.32 \pm 8.79\end{array}$ & \multirow[t]{2}{*}{$\begin{array}{l}60 \% \text { on VO2peak during } \\
30 \text { minutes }\end{array}$} \\
\hline & & & & & & & $\begin{array}{l}\text { Low } \mathrm{VO}_{2}: 34.69 \\
\pm 6.92\end{array}$ & \\
\hline Glaister et al. ${ }^{34}$ & $\begin{array}{l}16 \text { men cyclists } \\
\text { and triathletes }\end{array}$ & $38 \pm 8,0$ & $76.6 \pm 7,0$ & $180 \pm 5,0$ & - & $\begin{array}{l}\text { Cycle } \\
\text { Ergometric }\end{array}$ & $55,6 \pm 5,0$ & $\begin{array}{l}\text { Exercise } \\
\text { submaximal }\end{array}$ \\
\hline $\begin{array}{l}\text { Lopes-Silva et } \\
\text { al. }{ }^{31}\end{array}$ & $\begin{array}{l}10 \text { men athletes } \\
\text { and experienced } \\
\text { in taekwondo }\end{array}$ & $21 \pm 4,0$ & $71.0 \pm 12.9$ & $180 \pm 8,0$ & - & Fight & - & $\begin{array}{l}\text { Each combat consisted of } \\
\text { Three 2-min rounds with } 1 \text { - } \\
\text { min intervals }\end{array}$ \\
\hline Nelson et al. ${ }^{26}$ & $\begin{array}{l}\text { Eight men and } \\
\text { seven women } \\
\text { practicing } \\
\text { physical activity }\end{array}$ & $25.5 \pm 4.1$ & $77.9 \pm 18.4,0$ & & $25.1 \pm 4.0$ & $\begin{array}{l}\text { Cycle } \\
\text { Ergometric }\end{array}$ & $39.5 \pm 7.0$ & $\begin{array}{l}\text { Submaximal workload for } \\
30 \text { minutes, following by } 10 \\
\text { minutes ( } 80 \% \text { V02 max) and } \\
\text { additional } 10 \text { minutes ( } 100 \% \\
\text { V0). }\end{array}$ \\
\hline Rolim et al. ${ }^{32}$ & $\begin{array}{ll}21 & \text { young } \\
\text { physically } & \text { active } \\
\text { men } & \end{array}$ & $22.3 \pm 2.9$ & - & - & $\begin{array}{ll}25.2 & \pm \\
2.7 \mathrm{mg} / \mathrm{kg}^{2} & \end{array}$ & Treadmill & - & $\begin{array}{l}3 \text { minutes of warm-up at } \\
3 \mathrm{~km} / \mathrm{h} \text { and } 2.5 \% \text { of slope. In } \\
\text { sequence, increments } 1 \mathrm{~km} / \mathrm{h} \\
\text { each minute until reach } 85 \%\end{array}$ \\
\hline
\end{tabular}


of Maximal Heart Rate, test was interrupted. 
Table 2. Description of the selected articles by author and year, time ingestion CAF, CAF dose, placebo, analysis time, HRV index, main conclusions, strength of evidence and effect size through Cohen's d.

\begin{tabular}{|c|c|c|c|c|c|c|c|c|}
\hline Author/years & $\begin{array}{c}\text { Ingestion CAF } \\
\text { (before exercise) }\end{array}$ & $\begin{array}{l}\text { CAF } \\
\text { dose }\end{array}$ & Placebo & $\begin{array}{c}\text { Analysis } \\
\text { Time }\end{array}$ & HRV Index & Main conclusions & $\begin{array}{l}\text { Strength of } \\
\text { Evidence }\end{array}$ & $\begin{array}{c}\text { Cohens' } \\
\mathrm{d}=\end{array}$ \\
\hline $\begin{array}{l}\text { Kliszczewicz } \\
\text { et al. }{ }^{30}\end{array}$ & 45 minutes & $\begin{array}{c}(\sim 0.78 \mathrm{mg} / \mathrm{kg}) \\
100 \mathrm{mg}^{*}\end{array}$ & Capsule (dextrose) & $\begin{array}{l}45 \text { minutes } \\
\text { recovery post- } \\
\text { exercise }\end{array}$ & $\begin{array}{c}\operatorname{lnRMSSD}, \\
\operatorname{lnSDNN}, \operatorname{lnHF} \\
\left(\mathrm{ms}^{2}\right), \mathrm{HF}(\mathrm{nu}) \\
\operatorname{lnLF}\left(\mathrm{ms}^{2}\right), \mathrm{LF} \\
(\mathrm{nu}), \mathrm{LF} / \mathrm{HF}, \mathrm{HR}\end{array}$ & $\begin{array}{l}\text { During resting the CAF in } \\
\text { combination with the Citrus } \\
\text { Aurantium supplement induced } \\
\text { increase in the sympathetic } \\
\text { control without influencing the } \\
\text { parasympathetic regulation. It } \\
\text { did not influence cardiac } \\
\text { autonomic recovery. }\end{array}$ & $\begin{array}{c}\text { High } \\
\text { evidence }\end{array}$ & $\begin{array}{c}\text { HR: } 0.57, \\
\text { lnRMSSD: } \\
0.16, \\
\text { lnSDNN: } \\
1.28, \\
\operatorname{lnHF}: \\
0.11, \\
\text { HFnu: } \\
0.48, \operatorname{lnLF} \\
\left(\mathrm{ms}^{2}\right): 0.48, \\
\text { LFnu: } 0.55, \\
\text { LF/HF: } \\
0.18\end{array}$ \\
\hline $\begin{array}{l}\text { Smirmaul et } \\
\text { al. }^{36}\end{array}$ & 60 minutes & $\begin{array}{c}(4 \mathrm{mg} / \mathrm{kg}) \\
300 \pm 32 \mathrm{mg}\end{array}$ & $\begin{array}{c}\text { Capsule } \\
\text { (dehydrated milk) }\end{array}$ & 6 minutes & HR & $\begin{array}{l}\text { CAF increased HR in all tests } \\
\text { performed caused by increased } \\
\text { activation of the sympathetic } \\
\text { control. }\end{array}$ & $\begin{array}{c}\text { High } \\
\text { evidence }\end{array}$ & 0.67 \\
\hline
\end{tabular}




\begin{tabular}{|c|c|c|c|c|c|c|c|c|}
\hline $\begin{array}{c}\text { Gonzaga et } \\
\text { al. }^{32}\end{array}$ & 15 minutes & $\begin{array}{c}(\sim 3.80 \mathrm{mg} / \mathrm{kg}) \\
300 \mathrm{mg}\end{array}$ & Capsule (starch) & $\begin{array}{l}1,3,5,7,10, \\
20,30,40,50 \\
\text { and } 60 \\
\text { recovery } \\
\text { minutes post- } \\
\text { exercise }\end{array}$ & $\begin{array}{l}\text { RMSSD, SD1, } \\
\text { SDNN, HF, LF, } \\
\text { LF/HF, SAP, } \\
\text { DAP, HR }\end{array}$ & $\begin{array}{l}\text { Intake of CAF delayed the } \\
\text { parasympathetic recovery } \\
\text { following moderate aerobic } \\
\text { exercise. }\end{array}$ & $\begin{array}{c}\text { High } \\
\text { evidence }\end{array}$ & $\begin{array}{c}\text { Not } \\
\text { calculated. }\end{array}$ \\
\hline $\begin{array}{c}\text { Bunsawat et } \\
\text { al. }{ }^{31}\end{array}$ & 45 minutes & $\begin{array}{c}(\sim 5.06 \mathrm{mg} / \mathrm{kg}) \\
400 \mathrm{mg}\end{array}$ & Pills & $\begin{array}{l}5,15 \text { and } 30 \\
\text { minutes } \\
\text { recovery post- } \\
\text { exercise }\end{array}$ & $\begin{array}{c}\text { HR, DAP, SAP, } \\
\text { LF/HF }\end{array}$ & $\begin{array}{l}\text { The CAF group presented } \\
\text { higher HRmax during exercise. } \\
\text { BP, DAP and SBP values } \\
\text { remained elevated after the end } \\
\text { of the exercise. The CAF } \\
\text { delayed vagal reactivation after } \\
\text { exercise and caused } \\
\text { exacerbation of sympathetic } \\
\text { control. }\end{array}$ & $\begin{array}{c}\text { High } \\
\text { evidence }\end{array}$ & $\begin{array}{c}\text { Not } \\
\text { calculated. }\end{array}$ \\
\hline $\begin{array}{c}\text { Gonzaga et } \\
\text { al. }^{33}\end{array}$ & 15 minutes & $\begin{array}{c}(\sim 3.80 \mathrm{mg} / \mathrm{kg}) \\
300 \mathrm{mg}\end{array}$ & Capsule (starch) & $\begin{array}{l}60 \quad \text { minutes } \\
\text { recovery post- } \\
\text { exercise }\end{array}$ & $\begin{array}{l}\text { SDNN, RMSSD, } \\
\text { SD1, SD2, } \\
\text { LF(n.u.), } \\
\text { HF(n.u.), LF/HF }\end{array}$ & $\begin{array}{l}\text { Caffeine } \\
\text { parasympathetic recovery from } \\
\text { exercise in individuals with } \\
\text { lower cardiorespiratory } \\
\text { capacity (VO2 < } 42.46 \\
\mathrm{~mL} / \mathrm{kg} / \mathrm{min}) .\end{array}$ & $\begin{array}{l}\text { High } \\
\text { Evidence }\end{array}$ & $\begin{array}{c}\text { Not } \\
\text { calculated. }\end{array}$ \\
\hline
\end{tabular}




\begin{tabular}{|c|c|c|c|c|c|c|c|c|}
\hline $\begin{array}{c}\text { Glaister et } \\
\text { al. }^{37}\end{array}$ & 60 minutes & $\begin{array}{c}(5 \mathrm{mg} / \mathrm{kg}) \\
383 \pm 39 \mathrm{mg}\end{array}$ & $\begin{array}{c}\text { Capsule } \\
\text { (maltodextrin) }\end{array}$ & $\begin{array}{l}\text { 30minutes } \\
\text { recovery post- } \\
\text { exercise }\end{array}$ & HR & $\begin{array}{l}\text { CAF reduced resting } \mathrm{HR} \text { and } \\
\text { there was no impact of CAF on } \\
\text { HR recovery following } \\
\text { exercise. }\end{array}$ & $\begin{array}{c}\text { High } \\
\text { evidence }\end{array}$ & $\begin{array}{c}\text { Not } \\
\text { calculated. }\end{array}$ \\
\hline $\begin{array}{c}\text { Lopes-Silva et } \\
\text { al. }{ }^{34}\end{array}$ & 60 minutes & $\begin{array}{c}(5 \mathrm{mg} / \mathrm{kg}) \\
355 \pm 64,5 \mathrm{mg}\end{array}$ & $\begin{array}{c}\text { Capsule } \\
\text { (Cellulose) }\end{array}$ & $\begin{array}{c}180,360 \\
\text { seconds post- } \\
\text { exercise }\end{array}$ & RMSSD, HR & $\begin{array}{l}\text { CAF did not delay vagal } \\
\text { reactivation between } 180 \text { and } \\
360 \text { seconds following } \\
\text { exercise. }\end{array}$ & $\begin{array}{c}\text { High } \\
\text { evidence }\end{array}$ & $\begin{array}{l}\text { Resting } \\
\text { HR: } 0.48\end{array}$ \\
\hline Nelson et al. ${ }^{29}$ & 15 minutes & $\begin{array}{c}(2 \mathrm{mg} / \mathrm{kg})^{*} \\
173.4 \pm \\
35,2 \mathrm{mg}(\mathrm{men}) ; \\
135 \pm 8,8 \\
\text { (women) }\end{array}$ & $\begin{array}{l}\text { Liquid - Flavor- } \\
\text { matched. Beverage } \\
\text { non-caffeined } \\
\text { (Mountain Dew }{ }^{\circledR} \text { ) }\end{array}$ & $\begin{array}{l}\text { Ride time-to- } \\
\text { exhaustion } \\
\text { 20minutes } \\
\text { during } \\
\text { exercise. }\end{array}$ & $\begin{array}{c}\text { RMSSD, SDNN, } \\
\text { pNN50, LF, HF, } \\
\text { LF/HF, HR }\end{array}$ & $\begin{array}{l}\text { CAF in combination with } \\
\text { taurine increased resting HR, } \\
\text { however, no differences were } \\
\text { found in the linear time domain } \\
\text { and HRV frequency indices } \\
\text { between the placebo and CAF } \\
\text { groups. }\end{array}$ & $\begin{array}{c}\text { High } \\
\text { evidence }\end{array}$ & $\begin{array}{c}\text { Not } \\
\text { calculated. }\end{array}$ \\
\hline Rolim et al. ${ }^{35}$ & 60 minutes & $3 \mathrm{mg} / \mathrm{kg}$ & Capsule & $\begin{array}{l}60 \text { to } 300 \\
\text { seconds post- } \\
\text { exercise, with } \\
\text { the treadmill } \\
\text { vecolity } \\
\text { reduced to } \\
2.4 \mathrm{~km} / \mathrm{h} \text {. }\end{array}$ & $\begin{array}{l}\text { HR, SAP, DAP, } \\
\text { SD1,SD2 }\end{array}$ & $\begin{array}{l}\text { CAF accelerated } \\
\text { parasympathetic reactivation in } \\
\text { the submaximal exercise test in } \\
\text { the first three minutes. }\end{array}$ & $\begin{array}{c}\text { High } \\
\text { evidence }\end{array}$ & $\begin{array}{c}\text { SD1 at } 60 \\
\text { s: } 0.23, \\
\text { SD1 at } \\
\text { 120s: } 0.19 \text {, } \\
\text { SD1 at } \\
\text { 180s: } 0.27 \text {, } \\
\text { SD1 at } \\
\text { 240s: } 0.17 \text {, } \\
\text { SD1 at } \\
\text { 300s: } 0.23 \text {. }\end{array}$ \\
\hline
\end{tabular}


